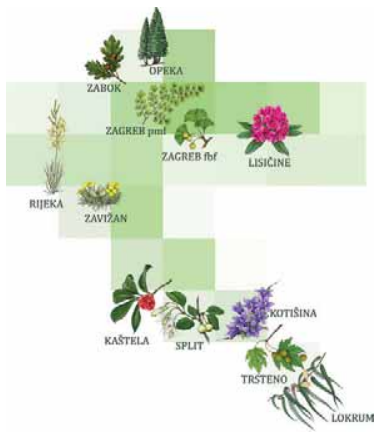

DOI: $10.2478 / \mathrm{v} 10184-010-0025-2$

\title{
First national week of Croatian botanical gardens and arboreta (May 30 - June 4, 2011)
}

Although it has only a few botanical gardens, Croatia is a member of the European Botanic Gardens Consortium, convened by the Botanic Gardens Conservation International $(B G C I)$. Croatian botanical gardens are recognized for their valuable collections of indigenous flora, the third richest in Europe, while the few arboreta keep collections of ornamental trees and shrubs older than 300 years. Most Croatian botanical gardens are statutorily protected, and all operate as integrated units of different faculties, schools or similar, rather than as independent institutions. Botanical garden employees (biologists, foresters, agronomists, horticulturists, teachers) gathered in 2009 to constitute a Section of Croatian Botanical Gardens and Arboreta, within the Croatian Botanical Society. That was the easiest way of fulfilling some of the elementary BGCI-tasks: to share resources and expertise, get a stronger constituency and voice, and cope with a number of different matters.

At the Round Table of the Section, organized during Third Croatian Botanical Congress (September 2011), the idea of an »Open Day « of Croatian botanical gardens was accepted. It was than decided that the »Open Day « should be extended to a Week of Croatian Botanical Gardens and Arboreta, in order to gain more attention from the public and the authorities. The Week would be accompanied by the First National Symposium of the Croatian Botanical Gardens and Arboreta, as well as an exhibition on the same subject. Six Croatian ministries agreed that the event would take place under their auspices, as did the State Institute for Nature Protection, the universities of Zagreb, Split and Dubrovnik, and the cities of Zagreb and Dubrovnik.

The Symposium was held on May $30^{\text {th }}$ in the exhibition pavilion in the Botanical Garden (Fig. 1), gathering 33 participants, 15 representatives of the sponsors and donators and more than 50 listeners. Twelve presentations on Croatian botanical gardens, arboreta and several other plant-collections were held, as well as presentations by invited lecturers $-\mathrm{Ms}$ Suzanne Sharrock, director of the BGCI-global programmes, and Dr Jože Bavcon, director of Ljubljana Botanic Garden (Slovenia). Two opening lectures were presented by Croatian representative in $B G C I$, Ms Biserka Juretić, who is also the manager of Zagreb Botanical Garden of the Faculty of Science, and Dr Antun Alegro, president of the Croatian Botanical Society. Summarized presentations of all the participants were published in the Booklet of Abstracts (in Croatian).

Copyright $^{\circledR} 2011$ by Acta Botanica Croatica, the Faculty of Science, University of Zagreb. All rights reserved. 


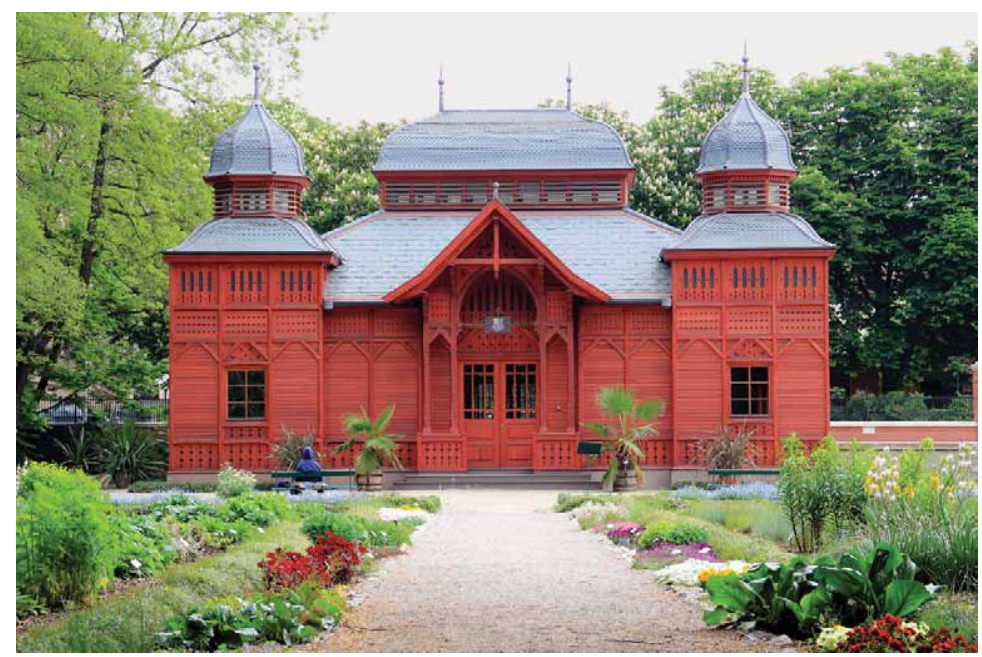

Fig. 1. Exhibition pavilion in the Botanical Garden of the Faculty of Science, University of Zagreb.

During the Week that followed, various events open daily to the public without charge were organized in 12 Croatian botanical gardens, arboreta and other facilities with smaller plant collections. In Dubrovnik, many students attended workshops and guided tours of the garden on the island of Lokrum (Botanical Garden of the Institute for Marine and Coastal Research, University of Dubrovnik), famous for its collection of Australian plants. In the more mysterious parts of the nearby Arboretum of the Croatian Academy of Arts and Science in Trsteno, the oldest existing arboretum in the world (founded in 1498), story-tellings were organized for children and their parents, along with workshops, lectures and guided tours. In the Marjan Botanical Garden of the Faculty of Science, University of Split, many citizens and pupils attended different workshops and lectures, expressing their hope that this neglected University Botanical Garden would be soon restored to its former beauty. The nearby city of Kaštela is home to the Ostrog Elementary School Botanical Garden, long-known for its rich and beautiful exotic plants collection. Pupils and their teachers prepared various workshops, guided tours and competitions in recognizing garden plants. This School was given the honour of organizing the official closing of the First National Week of the Botanical Gardens and Arboreta. At the event that took place on June 4, awards were given to the best young botanists. In the Kotišina Visitors Centre of the Biokovo Mountain Botanical Garden (Biokovo Nature Park) near the city of Makarska, lectures, tours and presentations were given daily, as well as a screening of the documentary film »Endemics of the Biokovo Mountain«. Because Mt Velebit Botanical Garden (Northern Velebit National Park) is fairly remote, situated high in the mountains of Zavižan, the biologist of the National park service went on a »botanical tour « through the cities and communities in the valley: in Gospić, Senj, Otočac and Krasno she organized various workshops and lectures in elementary schools and public libraries, in order to bring attention to the Velebit Botanical Garden and its valuable collection of local endemic plant species. The live plants collection of the Liburnian karst flora growing in the small Botanical Garden of the Natural History Museum in Rijeka was presented to public, and various other events included the presentation of the QR-codes in the Garden and the Museum, and an evening cocktail-party 
with non-alcoholic herbal beverages. The oldest statutorily protected monument of horticultural architecture in Croatia, the Opeka Arboretum in Vinica (near City of Varaždin) suffers greatly from irregular maintenance, being treated today as just a 'park' with no full-time employees. The organisation of the Week was thus carried out by the nearby Arboretum Opeka High School. Pupils and their teachers presented to the public various school-projects, photo-exhibitions and workshops, all related to the Arboretum situated literally across the street. The students of the Antun Gustav Matoš Grammar School (Zabok) started a lovely young arboretum of their own. They participated in the Week with various projects and presentations, meant for their parents and co-citizens. On the slopes of the northeast-Croatian Papuk Mountain, in the village of Lisičine, a large arboretum established in the 1960s was badly damaged during the Croatian War of Independence. The Arboretum is administered by the local Forestry Service, which organized guided tours for the students and citizens. Both botanical gardens of Zagreb University came up with various events. The Fran Kušan Pharmaceutical Botanical Garden (Faculty of Pharmacy and Biochemistry) gave information to visitors on poisonous and curative plants. The Botanical Garden of the Zagreb Faculty of Science offered 15 guided tours, 8 workshops, 8 lectures, 2 puppet-shows (Fig. 2) and an exhibition on Croatian botanical gardens and arboreta.

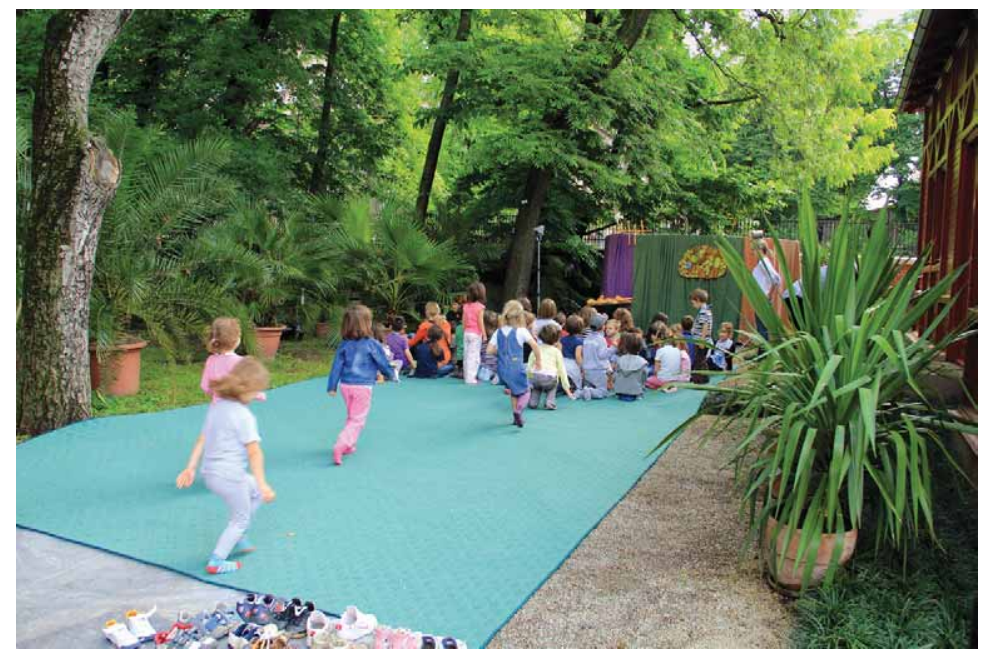

Fig. 2. The youngest Garden visitors taking their places for the puppet show.

The First National Week of Croatian Botanical Gardens and Arboreta, organized at 12 locations, was visited by more than two thousand people. Croatian Radiotelevision broadcast daily from different gardens and collections, bringing various Week events to a million viewers and listeners. Gardens and events during the Week were covered by a large number of newspapers and web sites. Many scientific, cultural and popular institutions and societies advertised the programme, inviting the public to visit their local botanical collections. Because of positive attention given to the first national Week of Croatian Botanical Gardens and Arboreta by the public, the media, as well as local communities, national authorities and institutions, we conclude it was a success and propose it become an annual event. 
The next National Week of Croatian Botanical Gardens and Arboreta will be organised from Monday $14^{\text {th }}$ to Saturday $19^{\text {th }}$ of May, 2012.

Sanja Kovačić and Vanja Stamenković, Department of Botany, Botanical Garden, Division of Biology, Faculty of Science, University of Zagreb

Marulićev trg 9a, HR - 10000 Zagreb, Croatia e-mail: sanja@botanic.hr 